\title{
Sentiment Analysis Of Full Day School Policy Comment Using Naïve Bayes Classifier Algorithm
}

\author{
Miftahul Kahfi Al Fath ${ }^{1)}$, Arini ${ }^{2)}$, Nashrul Hakiem ${ }^{3)}$ \\ ${ }^{122) 3)}$ State Islamic University Syarif Hidayatullah Jakarta , Indonesia \\ ${ }^{1}$ kahfialfath@gmail.com, ${ }^{2)}$ arini@uinjkt.ac.id, ${ }^{3}$ hakiem@uinjkt.ac.id
}

Submitted : May 23, 2020 | Accepted : Oct 1, 2020 | Published : Oct 8, 2020

\begin{abstract}
Sentiment analysis is an important and emerging research topic today. Sentiment analysis is done to see opinion or tendency of opinion to a problem or object by someone, whether tends to have negative or positive view. The main purpose of this study is to find out public sentiment on Full Day school's policy comment from Facebook Page of Kemendikbud RI and to find out the performance of the Naïve Bayes Classifier Algorithm. In this study, the authors used the Naïve Bayes Classifier algorithm with trigram and quadgram character feature selection with two different training data model and labeling of training data using Lexicon Based method in the classification of public sentiment toward the Full day school policy. The result of this research shows that public negative sentiment toward Full Day School policy is higher than positive or neutral sentiment. The highest of accuracy value is Naïve Bayes Classifier algorithm with trigram feature selection of 300 data training model with value $80 \%$. This simulation has proven that the greater of training data and feature selection used on the NBC Algorithm affected the accuracy result. Meanwhile, the result of simulation from 10 testing data with 5 different NBC and Lexicon algorithm also show that Full Day School Policy proposed by Minister of Education and Culture of Indonesia has negative sentiment higher than either positive or neutral by most of Facebook Users who state their opinion through comment.
\end{abstract}

Keywords: Sentiment Analysis; Naïve Bayes Classifier; Lexicon Based Method

\section{INTRODUCTION}

The rapid improvement of digital technology in recent years has become trigger in the society to use social media as main tool to connect and interact with families, friends and colleagues. There were top there social media platform that most frequently used with Indonesia people such Facebook. Instagram and Twitter. According to data from Asosiasi Penyelenggara Jasa Internet Indonesia also known as APJII stated in their survey that Facebook has the greatest visitor with 71,6 million visitor or 54\% from Indonesia population followed by Instagram with 19,9 million (15\%) and Youtube with 14,5 million (11\%) in 2016.

In the other hand, The Minister of Education and Culture of RI Muhadjir Effendy published a new regulation regarding Full Day School Policy through Permendikbud No 23 in the year of 2017. This Permendikbud was viral and has be pros and cons among citizens once this regulation was published. Realized with the growth of social media which always increased especially with Facebook, The Ministry of Education and Culture start to socialize the Permendikbud Policy of Full Day School through their official Facebook Page called "Kemdikbud.RI". There were a lot of opinion stated through comments from Facebook users both positive and negative one in responding Full Day school Policy. These comments could be more analyzed in order to find out whether Full Day School policy was accepted or not to be implemented in entire schools in Indonesia with method called by Sentiment Analysis.

Sentiment analysis is the process of understanding, extracting and processing textual data automatically to get sentiment information contained in an opinion sentence. Sentiment analysis is done to see opinion or propensity opinion to a problem or object by someone, whether tends to view negative or positif (Rozi, 2012). Sentiment analysis can use classification algorithm in text mining field such as Naive Bayes, Decision Tree, C.45, k-NN and so forth. The Naive Bayes algorithm can be used and has a pretty good result in classifying sentiments compared to other algorithms (Rachmat \&Lukito, 2016).

\footnotetext{
* Corresponding Author
} 
This study discusses the sentiment analysis of Full Day School policy from Facebook Page of Kemendikbud RI using Algorithm Naïve Bayes Classifier. Naïve Bayes algorithm in the authors' research used tri-gram and quad-gram character feature selection and used two different models of training data, 200 and 300 training data. The purpose of this research is to find out public sentiment in Full Day school policy comment from Facebook of Kemendikbud RI using Naïve Bayes Classifier (NBC) Algorithm and to find out the implementation and performance of Naïve Bayes Classifier Algorithm with Tri-gram and Quad-gram Character feature selection with different training data model.

\section{LITERATURE REVIEW}

In a study entitled "Political Comment Sentiment Classification from Facebook Page Using Naïve Bayes", sentiment analysis was applied to find out the sentiment of the public against the presidential candidate of the Republic of Indonesia in the 2014 election. Sentiments were taken from public comments from the official Facebook page of the Indonesian presidential candidate with the collection data 68 status with 3400 comments. The data has been obtained, then preprocessed tokenized, stemmed, weighted tokens, then continued classification with Naïve Bayes method, and tested using confusion matrix (Rachmat \&Lukito, 2016).

Then, in a study entitled "Sentiment Analysis on Twitter Social Media Using Naive Bayes Classifier Against Keywords Curriculum 2013", sentiment analysis is used to find out public sentiment towards the 2013 curriculum through social media twitter by utilizing the Twitter Search API to retrieve data from twitter, then apply process $\mathrm{n}$-gram characters for feature selection as well as using the Naive Bayes Classifier algorithm to classify sentiments automatically. This study uses 3300 data tweets about sentiment to the keyword "curriculum 2013". The data are classified manually and divided into 1000 data each for positive, negative and neutral sentiments (Pamungkas, Setiyanto \& Dolphina, 2015).

Furthermore, in a study entitled "Sentiment Analysis on Television Events Based on Public Opinion", sentiment analysis is implemented to find out public sentiment towards television displayed through social media twitter by utilizing the twitter API. Data obtained from twitter, then classified the sentiments by using Naïve Bayes algorithm and assisted preprocessing process that aims to remove the nonessential parts and also change the form of documents in the form of tweet to the standard form so that the classification made by Naïve Bayes be more accurate (Sentiaji \& Bachtiar, 2014).

In a study entitled "Application of the Naive Bayes Method to a Decision Support System to provide Discounts (Case Study: PT. Bina Usaha Teknik)" Classification was conducted by Naïve Bayes method as decision support system in granting discount to company product with some criterion specified by company, purchasing item, product status, big day and price range. The result of this study found that the application of decision support system to provide discounts using the Naïve Bayes method can provide an alternative to manage data quickly in providing provisional price recommendatio (Burdi, Setianingrum, \& Hakiem, 2017).

Finally, in a study entitle with "Analysis of Public Sentiment towards the 2014 Indonesian Presidential Candidate based on Opinion from Twitter", Naïve Bayes Classifier Algorithm used in opinion classification against president candidates after several steps has been conducted previously such collecting data, processing data and POS Tagging. (Nurhuda \& Sihwi, 2014)

The previous studies used Naïve Bayes Algorithm similar to the authors' research. The difference between the author's study lies in the feature selection used, classified data and case studies.

\section{METHOD}

In this research, there are two methods used those are data collection method and simulation method.

\section{Data Collection Method}

Data collection method used is literature study and field study using observation method. In literature study the authors collect data from books, journals or similar literature related to the author's research as a reference so as to assist authors in doing this research. In the field study, the authors observed and retrieved data from the Facebook API about Netizen Comments on Full Day School Policy (FDS) postings from the official Facebook Page of Kemendikbud RI. Researchers took data on September 25, 2017.

\section{Simulation Method}

There are different types of lifecycle that can be used for studies on modeling and simulation. The simulation stage in this research is Problem Formulation, Conceptual Model, Collection of Input / Output Data, Modelling Phase, Simulation Phase, Verification, Validation, and Experimentation, Output Analysis Phase (Madani, Kazmi \& Mahlknecht, 2010).

\section{Problem Simulation}

Based on the three previous studies in the second chapter, authors found the analysis result that the Naive Bayes Classifier Algorithm in the previous study only used one feature selection and the classification of training data sentiment was done manually. 
In this research the author used Naïve Bayes Classifer Algorithm with two features selection are Trigram and Quadgram character with the sentiment classification of training data using Lexicon Based method.

Each feature selection uses two different models of training data, namely 200 and 300 data training models.

\section{Conceptual Model}

In this research, conceptual model discusses the whole of this research. First by identifying input in this study, was netizen comments related to Full Day School policy. Second, comments that have been collected were then processed with Naïve Bayes Classifier Algorithm with Tri-gram feature selection and Quad-gram feature selection manually.

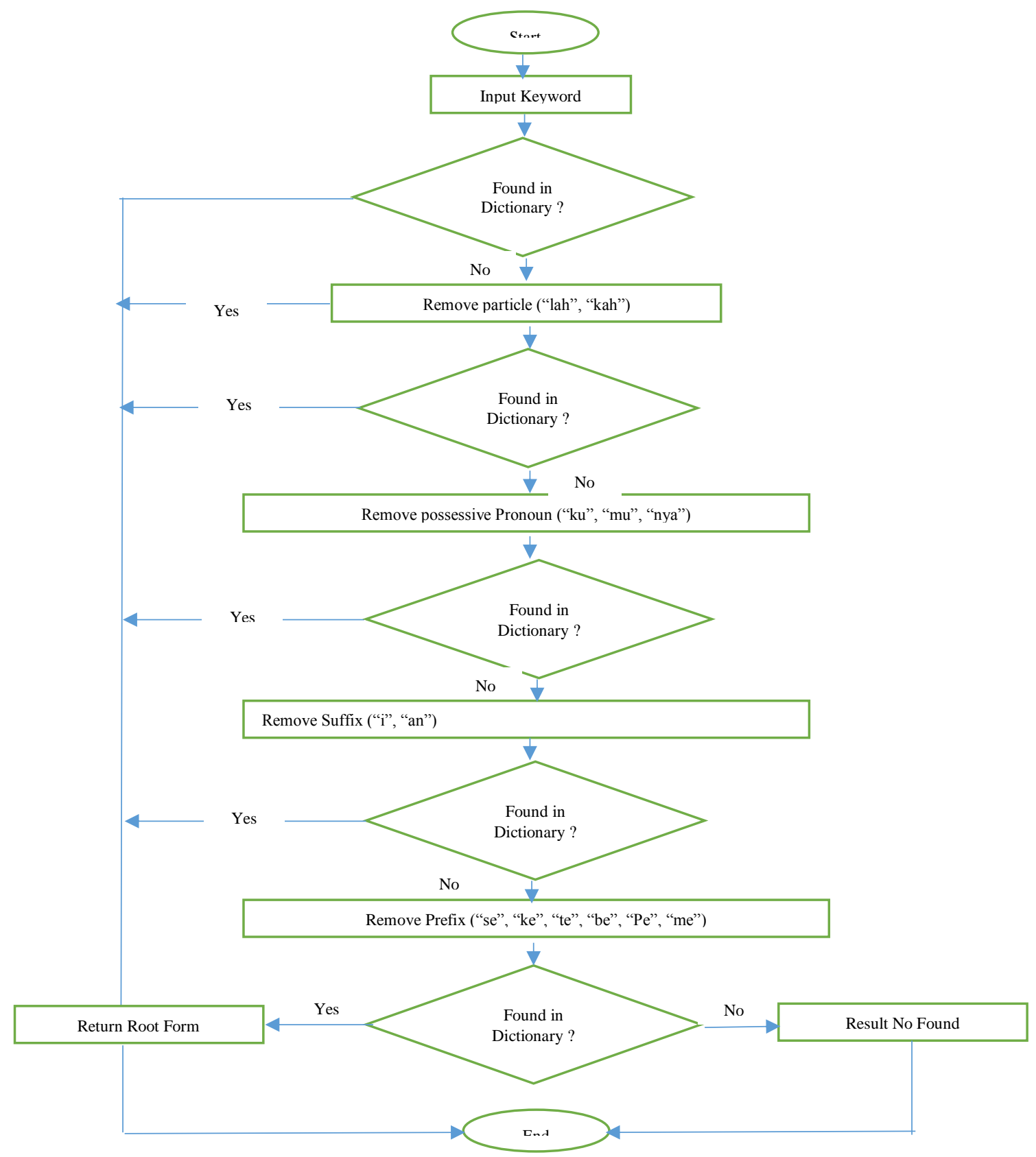

Fig. 1 Nazief \& Andriani Stemming Procedure

After processed manually, then made the comparison between Naïve Bayes Algorithm with Tri- gram feature selection of 200 Data Training model and 300 Data Training model and Quad-gram feature selection of 200 Data Training and 300 Data Training Model with classification or labeling sentiment of training data by Lexicon Based method. So there are four results of accuracy level that can be compared. 


\section{Collection of Input/Output Data}

Data obtained from netizen comments on the policy of full day school on the post of Official Page Kemmikbud RI. Total there are 310 comments divided into 300 training data and 10 test data. In addition to data from the Facebook API, there are positive lexicon and negative lexicon for labeling of training data and testing data (actual class). The result or output obtained from this research is the result of $\mathrm{N}$ gram feature selection and testing data that has been classified.

After processed manually, then made the comparison between Naïve Bayes Algorithm with Tri- gram feature selection of 200 Data Training model and 300 Data Training model and Quad-gram feature selection of 200 Data Training and 300 Data Training Model with classification or labeling sentiment of training data by Lexicon Based method. So there are four results of accuracy level that can be compared.

\section{Modelling Phase}

In Naïve Bayes Classifier algorithm construction consists of two stages of training phase and testing phase.

1. Training Phase

a. Take training data of every sentiment (positive, negative and neutral)

b. Training data then processed using text processing (case folding, cleansing, stopword removal)

c. After processed then training data is stemmed. For stemming procedure the authors used Nazief \& Andriani Algorithm. The procedures of Nazief and Andriani stemming algorithm is described in Figure 1 (Aulia, Khairani, akiem \& Durachman, 2017).

d. Select the Tri-gram or Quad-gram feature selection

e. Feature selection with $\mathrm{n}$ grams selected

f. Calculate the frequency of each $n$ gram

g. Calculate the total $\mathrm{n}$ gram of words

h. Calculate the probability of each $n$ gram (Indrayuni \& Wahyudi, 2015)

$$
P\langle X i \mid V j\rangle=\frac{n k+1}{n+|w o r d|}
$$

i. Calculate the probability of each sentiment document (Indrayuni \& Wahyudi, 2015)

\section{Testing Phase}

$$
P(V j)=\frac{\mid \text { docsj } \mid}{\mid \text { sample } \mid}
$$
a. Take testing data
b. Testing data then processed using text processing (case folding, cleansing, stopword removal)
c. After processed then testing data is stemmed. For stemming procedure the authors used Nazief \&
Andriani Algorithm. The procedures of Nazief and Andriani stemming algorithm is described in Figure 1 (Aulia, Khairani, akiem \& Durachman, 2017).
d. Select the Tri-gram or Quad-gram feature selection
e. $\mathrm{N}$ gram feature selection
f. Calculate the frequency of occurrence of each $n$ gram
g. Comparing $\mathrm{n}$ grams of testing data with $\mathrm{n}$ grams of data training every sentiment.
$\mathrm{h}$. If $\mathrm{n}$ gram testing data is equal to $\mathrm{n}$ gram of training data, then $\mathrm{n}$ gram robability of training data becomes $n$ gram probability of testing data.
i. if not, then the $\mathrm{n}$ gram frequency of the testing data is 0 , and then calculate the probability of the testing data $\mathrm{n}$ gram
j. $\quad$ Calculate the Vmap value of each sentiment category (Indrayuni \& Wahyudi, 2015).

$$
V m a p=\prod_{V j e V}^{a r \max }{ }_{i-1}^{n} P(X i \mid V j) P(V j)
$$

k. Take the highest Vmap Value from each sentiment category

1. Testing data is classified

\section{Simulation Phase}

In this simulation phase will be simulated Full Day School Policy Sentiment Analysis Using Naïve Bayes Classifier Algorithm according to the table 1. 
Table 1

Phase Of NBC Algorithm

\begin{tabular}{lr}
\hline $\begin{array}{c}\text { Variable/Simulation } \\
\text { Parameter }\end{array}$ & SIMULATION PHASE \\
\hline Factor 1 & $\begin{array}{r}\text { Data training phase with Naïve Bayes Classifier } \\
\text { Algorithm based on sentiments, feature selection and data } \\
\text { training model } \\
\text { Factor 2 }\end{array}$ \\
Factor 3 & $\begin{array}{r}\text { Data testing phase with Naïve Bayes Classifier Algorithm } \\
\text { based on feature selection and data training model } \\
\text { Accuracy testing phase of each NBC Algorithm }\end{array}$ \\
\hline
\end{tabular}

The simulation results from the table I are in accordance with the Figure 2, Figure 3 and Figure 4. The Figure 2 is a simulation of positive sentiment training phase with trigram feature selection of 200 training data model which has been calculated probability of each keyword. The Figure 3 described the results of the classification of NBC algorithm with the trigram feature selection of 200 training data model. The classification process is implemented by calculating the probability value of each sentiment. Before calculating the probability of each sentiment the keyword of $n$ gram data that has been stored in the database is compared to the keyword of training data. If the keyword in the testing data is equal as the keyword in the training data, then the probability of keyword in training data becomes the probability of keyword in testing data. Conversely, if not the same then the system will calculate the probability of keyword. Once the probability of all the keywords in each sentiment is obtained, then the Vmap value can be calculated. To determine the sentiment is taken the highest Vmap value of all sentiment. In the Fig.4 obtained the highest Vmap value 1.9637096024859E-255 with negative sentiment.

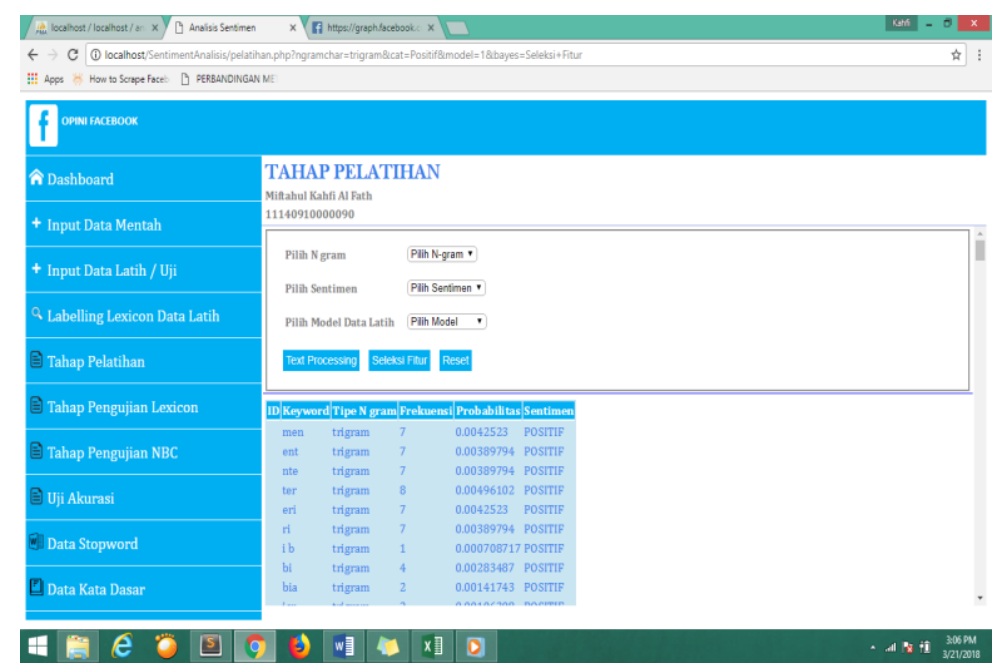

Fig. 2 Simulation of TrainingPhase

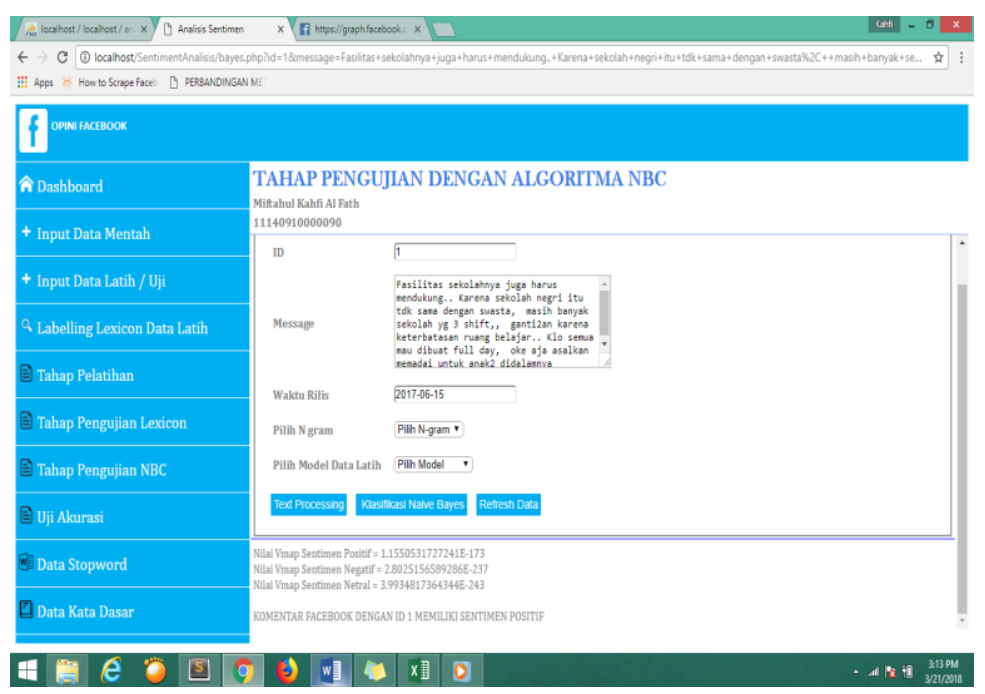

Fig. 3 Simulation of Algorithm NBC Testing Phase 


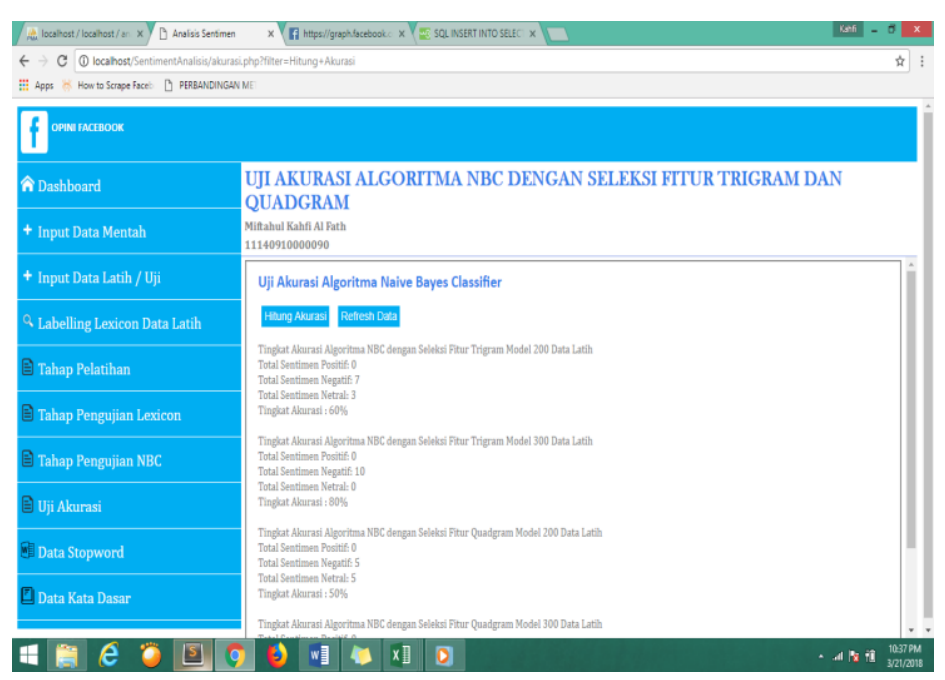

Fig. 4 Vmap Result

In the simulation of accuracy testing obtained the result that the accuracy of $\mathrm{NBC}$ algorithm with trigram feature selection of model 300 training data is higher than the accuracy value of other NBC algorithm that is equal to $80 \%$. To calculate the accuracy value of each feature selection, the authors used the following formula (4).

$$
\text { Accuracy }=\frac{\text { TruePositive }+ \text { TrueNegative }+ \text { TrueNeutral }}{\text { TotalofTestingData }}
$$

The followings are the results of our research.

\section{RESULT}

\section{Verification, Validation, and Experimentation}

Researchers perform verification to ensure each stage that has been done previously has a linkage and produce output in accordance with the expected. Furthermore, in the validation process conducted testing of the truth of NBC algorithm by comparing the performance of each NBC algorithm in term of accuracy and experimentation by comparing the results of scenarios that is the result of sentiment classification of testing data on each NBC Algorithm. From the experiment, the output analysis will be discussed at the Output Analysis Phase

\section{Output Analysis Phase}

In this phase described the output of classification of 10 testing data taken from netizen comments on the full day school policy of the Indonesian Ministry of Culture and education. Because of the classification using NBC algorithm with two different features selection and two training data models, and using Lexicon Based method to find out the actual sentiment of 10 testing data, so in this research there are five output classification sentiment which are described at the Table 2.

Table 2

Classification of NBC Sentiment Result

\begin{tabular}{cccccc}
\hline \hline \multirow{2}{*}{ Data to $\mathrm{n}$} & \multicolumn{5}{c}{ CLASSIFICATION OF NBC SENTIMENT RESULT } \\
& Trigram & Trigram & Quadgram & Quadgram & Lexicon \\
& Model $1^{*}$ & Model 2** & Model 1* & Model 2** & Based Method \\
\hline 1 & Neutral & Negative & Neutral & Negative & Negative \\
2 & Negative & Negative & Negative & Negative & Negative \\
3 & Negative & Negative & Neutral & Negative & Negative \\
4 & Negative & Negative & Negative & Negative & Negative \\
5 & Negative & Negative & Negative & Negative & Negative \\
6 & Negative & Negative & Negative & Negative & Negative \\
7 & Negative & Negative & Negative & Negative & Negative \\
8 & Negative & Negative & Neutral & Negative & Positive \\
9 & Neutral & Negative & Neutral & Negative & Positive \\
10 & Neutral & Negative & Neutral & Negative & Negative \\
\hline
\end{tabular}


*Model 1 represent 200 training data **Model 2 represent 300 training data

In this chapter analysis of the accuracy of the Naïve Bayes Classifier (NBC) algorithm with tri-gram and quadgram feature selection with two different training data model are presented. In the simulation that has been done obtained graphic results as follows, depict at figure 5 .

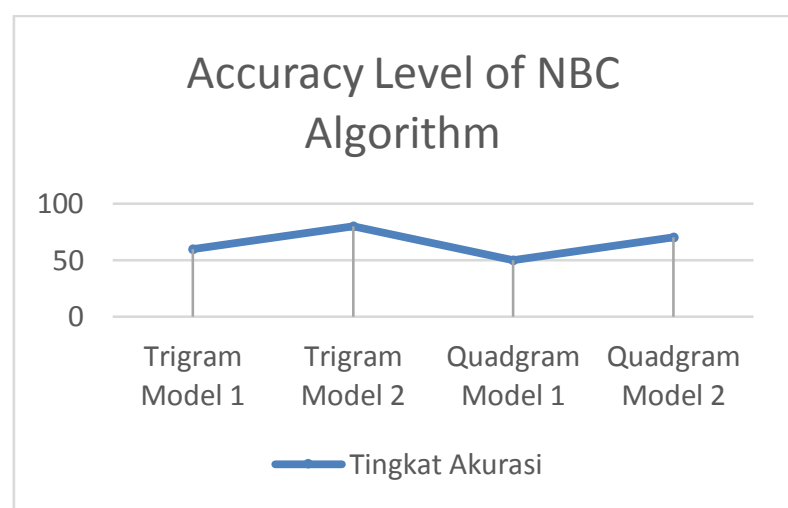

Fig. 5 Graph of Accuracy Level of NBC Algorithm

Table 3

Accuracy Level of NBC Algorithm

\begin{tabular}{lll}
\hline \hline & NBC Algorithm & $\begin{array}{l}\text { Accuracy } \\
\text { Value }\end{array}$ \\
\hline 1 & Trigram Model 1* & $60 \%$ \\
2 & Trigram Model 2** & $80 \%$ \\
3 & Quadgram Model 1* & $50 \%$ \\
4 & Quadgram Model 2** & $70 \%$ \\
\hline
\end{tabular}

*Model 1 represent 200 training data **Model 2 represent 300 training data

\section{DISCUSSIONS}

Based on the graph in figure 5 and table 3, received the following analysis :

1. NBC Algorithm Trigram feature selection has a higher level of accuracy than the NBC algorithm of quad gram feature selection using either 200 training data as well as 300 training data. In the study "The Implementation of Character N-Gram for Sentiment Analysis of Hotel Review Using Naive Bayes Algorithm" the accuracy value of quad gram feature selection is higher than the accuracy of trigram feature selection which is $83.67 \%$ and $84.67 \%$ respectively (Indrayuni \& Wahyudi, 2015). The result of accuracy of trigram and quad gram feature selection from previous research is different from writer's research. This difference occurs because in previous research the classification of training data is still manual while in author research the classification of training data already using Lexicon based method. The authors' analysis is supported by other research using the Lexicon Based method of "Improved Twitter Sentiment Analysis Using N Gram Feature Selection and Combinations" accuracy of trigram feature selection lower than two other feature selection (unigram and bigram) of $83.652 \%$ for unigram, $84,064 \%$ for bigram and 70,532\% for trigram (Awachate \& Kshirsagar, 2007). Based on the analysis of the author, it was found that the addition of $\mathrm{n}$ gram feature selection on NBC Algorithm has no effect in improving accuracy results if the classification of training data using Lexicon Based.

2. NBC algorithm with 300 training data model has a higher level of accuracy of NBC algorithm with 200 data training model using either trigram feature selection or quad gram feature selection. These results indicate that the more training data used, the higher the accuracy of the NBC Algorithm, because the NBC algorithm is a method of supervised learning that relies heavily on training data.

\section{CONCLUSION}

Based on the five sentiment classification results using Naïve Bayes Algorithm with two different feature selection and two training data models, it was found that public Negative sentiments in this case netizen who commented on the Full Day School (FDS) Policy on Facebook Page of Kemendikbud RI is greater than positive or neutral sentiment. Based on simulations conducted using Sentiment Analysis application built by the author using PHP Programming Language and Mysql database obtained results that the accuracy of Naivve Bayes Classifier (NBC) Algorithm with trigram feature selection of 300 training data model is higher than the NBC algorithm with trigram of 200 training data and the NBC algorithm with quadgram of 200 and 300 training data 
that is equal to $80 \%$. This simulation has proven that the greater of training data and feature selection used on the NBC Algorithm affected the accuracy result. Meanwhile, the result of simulation from 10 testing data with 5 different NBC and Lexicon algorithm also show that Full Day School Policy proposed by Minister of Education and Culture of Indonesia has negative sentiment higher than either positive or neutral by most of Facebook Users who state their opinion through comments. Writing this research, Author hope that government in this case Ministry of Education and Culture of RI could use this journal to be one of reference in evaluating whether Full Day School Policy supposed to discontinue or to be revised. For other researcher who want to use Naïve Bayes Algorithm in their research, Author hope this journal could be consideration in order to select which method is prefer to proceed training and testing data.

\section{REFERENCES}

Rozi, I. F., Pramono, S. H. and Dahlan, E. A. (2012) 'Implementasi Opinion Mining ( Analisis Sentimen ) untuk Ekstraksi Data Opini Publik pada Perguruan Tinggi', Electrical Power, Electronics, Communications, Controls, and Informatics Seminar (EECCIS), 6(1), pp. 37-43.

Rachmat, A., \& Lukito, Y. (2016). Klasifikasi Sentimen Komentar Politik dari Facebook Page Menggunakan Naive Bayes. Jurnal Informatika Dan Sistem Informasi Universitas Ciputra, 2(2), 26-34.

Pamungkas, D. S., Setiyanto, N. A., \& Dolphina, E. (2015). Analisis Sentiment Pada Sosial Media Twitter Menggunakan Naive Bayes Classifier Terhadap Kata Kunci "Kurikulum 2013'. Jurnal Teknologi Informasi, 14(4), 299-314.

Sentiaji, A. R., \& Bachtiar, A. M. (2014). Analisis Sentimen Terhadap Acara Televisi Berdasarkan Opini Publik. Jurnal Ilmiah Komputer Dan Informatika (KOMPUTA), 2(1), 55-60.

Burdi, F., Setianingrum, A. H., \&Hakiem., N., (2017), Application of the Naive Bayes Method to a Decision Support System to Provide Discounts (Case Study: PT. Bina Usaha Teknik), in Proceedings - 6th International Conference on Information and Communication Technology for the Muslim World, ICT4M 2016, no. November, pp. 281-285.

Nurhuda, F., \& Sihwi, S. W. (2014). Analisis Sentimen Masyarakat terhadap Calon Presiden Indonesia 2014 berdasarkan Opini dari Twitter Menggunakan Metode Naive ayes Classifier. ITSmart: Jurnal Ilmiah Teknologi Dan Informasi, 2(2), 35-42.

Matulatuwa, F. M., Studi, P., Sistem, M., Informasi, F. T., Kristen, U., \& Wacana, S. (2017). Text Mining dengan Metode Lexicon Based untuk Sentiment Analysis Pelayanan PT . POS Indonesia Melalui Media Sosial Twitter Jurnal, (September).

Islami, A. M. N. (2016). Implementasi Program Pendidikan Full Day School di Muhammadiyah Karanglo Kecamatan Cilondok Kabupaten Banyumas. IAIN Purwokerto.

Chandra, D. N., Indrawan, G., \& Sukajaya, I. N. (2016). Klasifikasi Berita Lokal Radar Malang Menggunakan Metode Naïve Bayes Dengan Fitur N-Gram. Jurnal Ilmiah Teknologi Dan Informasi ASIA (JITIKA), 1O(1), 11-19. Retrieved from http://lp3m.asia.ac.id/wp-content/uploads/2016/02/2.-jurnal-Denny.pdf

Wahyudi, D., Susyanto, T., \& Nugroho, D. (2017). Implementasi dan Analisis Algoritma Stemming Nazief \& Adriani dan Porter pada Dokumen Berbahasa Indonesia. Jurnal Ilmiah Sinus, 15(2), 49-56. Retrieved from p3m.sinus.ac.id/jurnal/index.php/e-jurnal_SINUS/article/download/305/pdf

Madani, S. A., Kazmi, J., \& Mahlknecht, S., (2010) Wireless sensor networks: modeling and simulation, Discret. Event Simulations, no. 2004, pp. 1-16, 2010.

Aulia, A., Khairani, D., Hakiem, N., \& Durachman, Y., (2017) Development of a Retrieval System for Al Hadith in Bahasa ( Case Study : Hadith Bukhari )," in 5th International Conference on Cyber and IT Service Management, 2017, no. August 2017, pp. 549-553.

Indrayuni, E., Wahyudi, M., Informasi, S., Selatan, J., Komputer, I., \& Selatan, J. (2015). Penerapan Charachter N-Gram Untuk Sentiment Review Hotel Menggunakan Algoritma Naive Bayes. In Konfrensi Nasional Ilmu Pengetahuan dan Teknologi (KNIT) (pp. 88-93). Bekasi.

P. B. Awachate, P. B., \& Kshirsagar, V.P., (2007), Improved Twitter Sentiment Analysis Using N Gram Feature Selection and Combinations, Int. J. Adv. Res. Comput. Commun. Eng. ISO, vol. 3297, no. 9, pp. 154-157

Nurhuda, F., \& Sihwi, S. W. (2014). Analisis Sentimen Masyarakat terhadap Calon Presiden Indonesia 2014 berdasarkan Opini dari Twitter Menggunakan Metode Naive Bayes Classifier. ITSmart: Jurnal Ilmiah Teknologi Dan Informasi, 2(2), 35-42. 